5. Lishchynska, O. (2013). 'Media art in Ukrainian visual art: philosophical and aesthetic ideas and expressions'. Hileia : naukovyi visnyk [Gilea: Scientific Bulletin], no. 78, pp. 256-259.

6. Prudenko, Ya. (2018). 'The Rabelais of Ukrainian video art. Oleksandr Roitburd', [online] Available at: <http://korydor.in.ua/texts/176-Rable-ukrainskogovideo-artu-Oleksandr-Roytburd> [Accessed 11 February 2018].

7. Sydorenko, V. (2008). Visual art from avant-garde shifts to new directions: the development of visual art of Ukraine in the $20^{\text {th }}$ and $21^{\text {st }}$ centuries. Kyiv: VH studio.

(C) Совгира T. I., 2018

УДК 791.22(477)“1953/1964”(075)

Сокол Олена Володимирівна здобувач, Київький національний університет культури і мистеитв, Київ, Україна sokolee@ukr.net

\title{
ТВОРЧИЙ ВСЕСВІТ КІНЕМАТОГРАФУ Т. В. ЛЕВЧУКА ПЕРІОДУ ХРУЩОВСЬКОЇ «ВІДЛИГИ»
}

Мета дослідження. Стаття присвячена творчій та громадській діяльності провідного українського радянського кінорежисера Т. В. Левчука в 19531964-х рр.: аналізується творчий доробок митця в контексті специфіки українського кіновиробництва, його діяльність в Спілці кінематографістів УРСР. Методологію статті становлять принципи об'єктивності та історизму, які базуються на проблемно-хронологічному, конкретно-історичному, описовому статистичному та логіко-аналітичному методах наукового пізнання. Наукова новизна статті полягає у висвітленні діяльності українського кінорежисера Т. В. Левчука в період хрущовської «відлиги», з використанням архівних матеріалів Київського національного університету театру, кіно і телебачення ім. І. К. Карпенка-Карого, фондів музею Національної кіностудії художніх фільмів ім. О. Довженка, критичних статей та рецензій, опублікованих у періодичній пресі, а також мемуарної літератури. Висновки. Особистий внесок Т. В. Левчука в розвиток українського кіновиробництва та професійної мистецької освіти важко переоцінити: за його поданням у 1961 p. Ради Міністрів УРСР ухвалила рішення про відкриття в Київському інституті театрального мистецтва кінофакультету, який повинен здійснити підготовку кадрів за спеціальностями: кінорежисура, кінооператорство та кінознавство; наслідком його педагогічної діяльності $\epsilon$ виховання славетної когорти кінорежисерів; а творчої діяльності - художньо-ігрові фільми: «Полум'я гніву» 
(1955 р.), «Іван Франко» (1956 р.), «Киянка» (1959 р.), «Закон Антарктиди» (1962р.), «Космічний сплав» (1964р.), які потребують сьогодні незаангажованого осмислення.

Ключові слова: Т. В. Левчук, кінорежисер, фільми, сценарій, рецензії, тематика, педагогічна та громадська діяльність.

Сокол Елена Владимировна, соисктель, Киевский начиональный университет культуры и искусств, Киев, Украина

Творческий мир кинематографа Т. В. Левчука периода хрущевской «оттепели»

Цель исследования. Статья посвящена творческой и общественной деятельности ведущего украинского советского кинорежиссера Т. В. Левчука в 1953-1964-х гг.: анализируется творческое наследие художника в контексте специфики украинского кинопроизводства, его деятельность в Союзе кинематографистов УССР. Методологию статьи составляют принципы объективности и историзма, основанные на проблемно-хронологическом, конкретно-историческом, описательно-статистическому и логико-аналитическом методах научного познания. Научная новизна статьи заключается в освещении деятельности украинского кинорежиссера Т. В. Левчука в период хрущевской «оттепели», с использованием архивных материалов Киевского национального университета театра, кино и телевидения им. И. К. Карпенко-Карого, фондов музея Национальной киностудии художественных фильмов им. А. Довженко, критических статей и рецензий, опубликованных в периодической печати, а также мемуарной литературы. Выводы. Личный вклад Т. В. Левчука в развитие украинского кинопроизводства и профессионального художественного образования трудно переоценить: по его представлению в 1961 г. Совета Министров УССР принял решение об открытии в Киевском институте театрального искусства кинофакультета, который должен осуществить подготовку кадров по специальностям: кинорежиссура, кинооператорство и киноведение; следствием его педагогической деятельности является воспитание славной когорты кинорежиссеров; а творческой деятельности художественно-игровые фильмы: «Пламя гнева» (1955 г.), «Иван Франко» (1956 г.), «Киевлянка» (1959 г.), «Закон Антарктиды» (1962 г.), «Космический сплав» (1964 г.), которые нуждаются сегодня переосмыслении.

Ключевые слова: Т. В. Левчук, кинорежиссер, фильмы, сценарии, рецензии, тематика, педагогическая и общественная деятельность.

Sokol Olena, postgraduate, Kyiv National University of Culture and Arts, Kyiv, Ukraine

The creative universe of $T$. Levchuk's cinematography during the Khrushchev's Thaw

The purpose of the article. The article is devoted to the creative and social activity of the leading Ukrainian Soviet film director, T. Levchuk, in 1953-1964: the creative work of the artist in the context of the specifics of Ukrainian film production 
and his membership in the Union of Cinematographers of the USSR were analyzed. The research methodology consisted in the principles of objectivity and historicism, based on the problem-chronological, specific-historical, descriptive, statistical and logical-analytical methods of scientific cognition. The scientific novelty of the work lies in highlighting the activity of the Ukrainian film director, T. Levchuk, during the period of the Khrushchev's Thaw, using the archival materials of Kyiv National I. K. Karpenko-Kary Theatre, Cinema and Television University, the collections of the Museum of the Dovzhenko Film Studios, critical articles and reviews published in periodicals, and memoirs. Conclusions. T. Levchuk's personal contribution to the development of Ukrainian film production and professional arts education is difficult to overestimate: at his request in 1961 the Council of Ministers of the USSR adopted a decision to open in Kyiv Theater Arts Institute the Department of Cinematography, which had to provide training in the following specialties: film directing, photography directing and film studies; the result of his teaching activity was the education of the glorious cohort of filmmakers; his creative activity resulted in feature films «The Flame of Wrath» (1955), «Ivan Franko» (1956), «A Woman From Kyiv» (1959), «The Law of Antarctica» (1962), «Space Alloy» (1964), which need rethinking today.

Key words: T. Levchuk, director, motion pictures, scripts, reviews, themes, educational and social activity.

Вступ. На сучасному етапі, в період розвитку української науки, культури i мистецтва, відродження кіновиробництва на тлі процесу становлення незалежної держави, актуальним завданням вітчизняних істориків, культурологів, мистецтво- та кінознавців стає неупереджене та прискіпливе вивчення творчого доробку українських митців, не 3 позиції доцільності, нав'язаною радянською ідеологією, а з позиції внеску в розвиток культури й мистецтва. Актуальність даної статті зумовлена необхідністю комплексного дослідження життя, творчої, громадської та педагогічної діяльності одного 3 провідних українських кінорежисерів художньо-ігрових фільмів другої пол. $\mathrm{XX}$ ст. - Т. В. Левчука, оскільки його особистий внесок в історію українського кіномистецтва, розвиток кіновиробництва та професійної мистецької освіти потребує детального всебічного вивчення, аналізу, висвітлення та уведення до наукового обігу, що особливо важливо в умовах становлення і розвитку вищої професійної мистецької освіти в Україні.

Мета дослідження. Стаття присвячена творчій та громадській діяльності провідного українського радянського кінорежисера Т. В. Левчука в 1953-1964х pp.: аналізується творчий доробок митця в контексті специфіки українського кіновиробництва, його діяльність в Спілці кінематографістів УРСР.

Аналіз публікацій. Історія українського радянського кіномистецтва протягом останніх десятиліть становить великий інтерес для вітчизняних науковців. Варто зазначити, що за перші роки незалежності України досліджень, наукових статей та розвідок які були присвячені історії радянського кінематографу або зародженню кіномистецтва незалежної України 
було замало і лише наприкінці 1990-х рр., завдяки науковій діяльності таких дослідників як Т. Журавльова, Н. Зайко, Д. Титаренко, Н. Ховайба, чиї роботи були присвячені дослідженню українського кіно 1940-60-х рр. та відомих нині кінознавців О. Безручка, Л. Брюховецької, I. Зубавіної, Р. Росляк, В. Скуратівського, С. Тримбача, Г. Погребняк та ін. розпочався якісно новий період в українському кінознавстві. Наукові праці О. Безручка та Р. Росляка присвячені історії та розвитку української кіноосвіти, проблемам сучасного та авторського кіно; Л. Брюховецька, 3 поміж величезного кола наукових інтересів, досліджує й творчість видатних українських режисерів (Л. Осика, I. Миколайчук, Ю. Іллєнко, Л. Биков); В. Скуратівський аналізує екранні мистецтва в соціокультурних процесах XX ст.; дослідження С. Тримбача присвячені історії та сучасності українського кіно. Проте, не дивлячись на величезний обсяг досліджуваного історичного матеріалу, творча та громадська діяльність Т. Левчука так і не знайшла комплексного вивчення, а була лише частково висвітлена в окремих публікаціях, розвідках та найбільш повно в мемуарній літературі. Відтак, 3 огляду на результати проведеного історіографічного аналізу, вважаємо за доцільне присвятити дане наукове дослідження творчості кінорежисера Т. Левчука, з метою висвітлення впливу його творчої, громадської та педагогічної діяльності на розвиток українського кіномистецтва та вищої професійної кіноосвіти в Україні.

Виклад основного матеріалу. Народний артист Тимофій Васильович Левчук (1912-1998рр.) увійшов в історію українського кіномистецтва як режисер традиційного реалістичного кіно, постановник кінофільмів військової тематики та першого українського кольорового широкоформатного художнього фільму «Закон Антарктиди» (1962р.); як педагог та професор Київського театрального інституту (1970 p.), перший секретар правління Спілки кінематографістів УРСР (1963-1987р.) та Спілки кінематографістів СРСР (3 1965 р.); а також автор книг: «В об'єктиві США і Канади» (1966 р.), «3 любов’ю до глядача» (1974 р.), «Закордонні зустрічі» (1976 р.), «Кіномистецтво Радянської України семидесятих років» (1980р.), «Кінорежисура» (у співавторстві, 1981 р.), «Люди і фільми» (1983 р.), «Тому що люблю: спогади кінорежисера» (1987 p.).

«Знаменним у його діяльності є відкритий потяг до значимості тем, до яскравості образу, до значимості свого героя» [6, с. 71].

Т. Левчук - автор понад двадцяти документальних та художньо-ігрових фільмів, створених на Київській кіностудії ім. О. Довженка, на яку влаштувався після закінчення режисерського факультету Київського кіноінституту в 1934 р. Спочатку працював асистентом режисера I. Кавалерідзе, який розпочав знімання україномовного історичного фільму «Прометей»; в 1939 р. асистентом режисера І. Савченка, який розпочав екранізацію «Вершників» Ю. Яновського; а в 1947 р. - другий режисер кінокартини «Голубі дороги» В. Брауна.

Відомий Т. Левчук як режисер дубляжу українською мовою та автор документальних фільмів - «Зоря над Карпатами» (1949 р.), «Київ» (1950р.), «Н.В. Гоголь» (1953р.); як режисер-постановник фільмів-спектаклів - 
«В степах України» (1952р.), «Калиновий гай» (1953р.); фільму-концерту «Співає Україна» (1954р.); художньо-ігрових фільмів - «Полум'я гніву» (1955 р.), «Іван Франко» (1956р.), «Киянка» (1959р.), «Закон Антарктиди» (1962 р.), «Космічний сплав» (1964р.), «Два роки над прірвою» (1966р.), «Помилка Оноре де Бальзака» (1968р.), «Родина Коцюбинських» (1970р.), «Довга дорога в короткий день» (1972р.), «Дума о Ковпаке» (1975р.), «Від Бугу до Вісли» (1980р.), «Ми звинувачуємо» (1985р.), «І в звуках пам’ять відгукнеться...» (1986р.), «Війна» (На західному напрямку) (у співавторстві з Г. Коханом; 1990 р., у 6-ти серіях), «Бухта смерті» (у співавторстві з Г. Коханом; 1991 р.) [5].

Режисерським дебютом Т. Левчука в художньо-ігровому кіно став історичний фільм «Полум'я гніву» (сценарій Л. Дмитерка), присвячений боротьбі українського народу за возз'єднання 3 Росією. Його прем'єра відбулася 13 липня 1956 р.

У знімальній групі працювали: оператор М. Кульчицький, композитор Б. Лятошинський, художник О. Бобровников, а також актори - М. Ільченко, Н. Ужвій, В. Ігнатенко, О. Романенко, М. Москаленко, В. Донська-Присяжнюк, М. Романов, А. Тарський, В. Каменецький, М. Яковченко, С. Шкурат, Ф. Іщенко, П. Грубник, М. Задніпровський, Ф. Радчук, Д. Мілютенко, О. Вертинський, М. Волков, В. Дуклер, Г. Бабенко, П. Бєлоконь, О. Подородний, А. Босенко.

У фільмі йшлося про події в Чигирині, де генеральний писар Іван Виговський готував змову та домагався гетьманської булави, покладаючись на підтримку татарського хана Кара-Бея. Натомість полковник Мартин Пушкар збирає козацьке військо і за допомогою російських загонів Апухтіна, розбивають війська зрадника.

Створюючи картину широкого епічного плану, основним прийомом режисерського втілення стали масові сцени та зіткнення двох протидіючих сил. За сценарієм Л. Дмитерка, написаному в жанрі народної оповіді, режисер Т. Левчук прагнув відтворити героїчні характери персонажів, жорстокість боротьби з ворогами та надати кінострічці патетичного звучання.

Про окремі недоліки режисерської роботи писали кінокритики в пресі, наприклад: Є. Хігерович у газеті «Тихоокеанская звезда» стверджував, що масові сцени позбавлені живих індивідуальних образів і «вирішені» на одну особу - «народ взагалі» [15], хоча обраний жанр «не виключає тонкої психологічної розробки характерів, їх точної індивідуалізації (...). Саме цього і не вистачає в роботі режисера, який спрощено вирішує багато образів...» [15]; О. Бауман у газеті «Правда України» (1958 р.) зазначала, що «коли дивишся такі картини, як “Коли співають солов'ї”, “Полум'я гніву”, “Долина синіх скель”, мимоволі думаєш, що їх творці забули велике і мудре правило мистецтва: навчати може лише той, хто розумніший, вище, краще тих, кого він навчає...» [1].

T. Левчук, визнавши, що фільм «не лишенный недостатков» [4, с. 20] все ж вважав його своєрідним іспитом режисерської зрілості, а невдовзі отримав сценарій Л. Смілянського. Історико-біографічна картина «Іван Франко», 
прем’єра якої відбулася в 1956 р., присвячена 100-річчю від дня народження українського письменника та громадського діяча. Оператором фільму був М. Кульчицький, художником-постановником В. Мігулько, музичне оформлення здійснили композитори М. Колесса та Б. Лятошинський. У фільмі брали участь відомі актори: С. Бондарчук, Л. Гриценко, І. Скобцева, Я. Геляс, О. Ліцувнович, В. Балашов та ін.

Як зазначив згодом режисер фільму Т. Левчук, картина була «тепло сприйнята глядачами і отримала хорошу оцінку в пресі» [4, с. 20]. Так, наприклад, в газеті «Правда» за 5 січня 1957 р. відзначалося, що «в сжатые рамки кинофильма авторы вложили наиболее существенные, особенно яркие и характерные эпизоды из жизни и революционной деятельности великого писателя. На широком историческом фоне они создали цельный образ человека с эрудицией ученого, с простодушием ребенка, с непобедимой волей бойца» $[4$, c. 24].

I хоча фільм Т. Левчука «Іван Франко» намагалися в ювілейний рік письменника номінувати на Ленінську премію, проте за кілька років він став приводом до упередженої критики на сторінках радянської преси. Дехто стверджував, що «ряд сцен напоминает фильмы-спектакли - так условнотеатральны их декорации, игра актеров и даже построение эпизодов, диалогов и т. д.» $[18$, с. 169], інші, наприклад, А. Михалевич, що в фільмі відсутня глибина проникнення та природна течія життя, відтак нема i правди, а атмосфера в яку занурений головний герой настільки штучна, що «даже стихи гениального Франко, в устах Бондарчука, умирают (...) Какая заманчивая задача и как это нужно - поведать миру об украинском титане Франко. Его незаслуженно мало знают. И какое обидное недостижение цели в фильме! Смотрю фильм. Всё, всё есть. И тюрьма. И церковь. И дети. И старики. И подлая конституция. И выборы в парламент. И стихи. И песни. И роскошные женщины, что соблазняют Франко точно так же, как соблазняли и Сковороду, и Джордано Бруно... Есть кузница. И молотом бьет герой. И редактирует. И обличает. И выстрелы есть. И свадьба. И бал. И похороны (...) Все дано торопливо, - некогда исследовать, открывать жизнь, вникать в психологию людей. Ведь всех надо упомянуть. Надо успеть «подставить» в эпизод Лысенко и подключить реплику: "Мыкола, написал бы ты музыку к "Вечному революционеру", - и Лысенко, конечно, тут же напишет... Происходит откровенная демонстрация “на публику”. Герои почти не разговаривают между собой: они говорят лишь для нас, чтобы мы были информированы, чтобы обязательно вынесли из картины все те сведения, которые проходили еще в школе...» [11, с. 13].

На думку рецензентів, при створенні фільму «Іван Франко», Т. Левчуку та Л. Смілянському було складно розкрити багатогранність творчого життя письменника, а тому «стремясь охватить как можно больше сторон его деятельности, они несколько увлеклись воспроизведением отдельных эпизодов жизни Франко, не всегда заботясь об их сюжетной связанности и художественной оправданности. Перед глазами зрителей в быстро 
мелькающих кадрах Франко предстает то на суде, то в селе, то на улице или у себя в квартире во Львове, а затем в Киеве и т. д. В фильме есть и удачные эпизоды, но в целом от картины не остается цельного впечатления, она фрагментарна» [7].

Образ I. Франка, у виконанні С. Бондарчука, теж викликав певні нарікання. Наприклад, В. Кирдан зауважував, що він дещо ідеалізований та схематичний; позбавлений будь-яких людських слабкостей, переживань та протиріч; зображений занадто послідовним і прямолінійним революціонером, що суттєво вплинуло на реалістичну правдивість образу: «заслуги Франко перед украинским народом и его культурой настолько велики, что он не нуждается в украшательстве. Вместе с тем в фильме невыразительно показана борьба Франко с украинскими буржуазными националистами [7]. До того ж, критик зазначив, що фільм “Іван Франко” викликає певні асоціативні зв”язки 3 картиною “Тарас Шевченко”, нарікаючи на те, що актор С. Бондарчук (виконавець головних ролей в обох фільмах. - Авт.) “не нашел новых ярких красок и во многом повторяется"» [7]. Утім, критик пояснює це не стільки невдалим трактуванням й відсутністю нових акторських засобів розкриття образу Франка С. Бондарчуком, скільки сценарними недоліками: «Жизнь и деятельность И. Франко, полные борьбы и напряженного разностороннего труда, давали авторам фильма благодатный материал для создания высокохудожественного произведения. Однако возможности эти оказались во многом не реализованы» [7].

В. Кузнецов, на сторінках журналу «Мистецтво кіно» зазначав, що при створенні багатьох фільмів на Київській кіностудії за основу береться тезис «Надо показать то-то». И “то-то” показывается - без всякой заботы о том, насколько оно органически включается в ткань фильма» [8, с. 104-105]. Для прикладу автор згадував фільм «Іван Франко», стверджуючи, що постановникам не вдалося глибоко й історично достовірно відобразити епоху та iï протиборчі суспільні сили, людські долі через надмірну калейдоскопічність подій: «появляется персонаж на экране. Кто-то из действующих лиц шепчет: “Это Лысенко!” И зрители должны верить на слово, ибо никаких ощутимых подтверждений того, что это - великий композитор, нет. Могут возразить: как в нескольких эпизодах достигнуть этого? А как классики литературы порой двумя-тремя строчками давали изумительные портреты своих современников?! Вот на экране Иван Франко... Он создает стих... Совершается тайна творчества. А что видит зритель? Шагает по ночной улице человек и в такт шагам слово за словом нижет строчки...» [8, с. 104-105].

Подібні негативні рецензії, зазвичай, які були замовлені, і свідчать, що поступове послаблення тоталітарного контролю, ідеологічного тиску та боротьби з національними проявами в період хрущовської «відлиги», насправді не мали нічого спільного 3 можливістю вільно виражати власні погляди засобами кіномистецтва. Більшість режисерів продовжували знімати фільми на політичне замовлення, безумовно, талановиті, насичені яскравими виражальними засобами кіно, але занадто заангажовані за змістом, а їхнє 
бажання звертатися до правдивого зображення української дійсності, вірогідно відтворювати історичні події та популяризувати українську культуру жорстко контролювалося радянською владою за допомогою художніх та редакційних рад кіностудій. Сценарій фільму обов'язково обговорювався і не було прецеденту, щоб текст лишався без виправлень, після чого «виправлений сценарій» редагувався головним редактором та подавався на розгляд у Держкіно УРСР. Лише після остаточного утвердження, розпочиналися зйомки фільму, якими опікувався редактор кіностудії, а після завершення комісія Держкіно УРСР вирішувала вийде фільм у прокат чи ні [3, с. 452].

Варто зазначити, що відомий кінокритик С. Тримбач, вважає стрічку «Іван Франко» першим справжнім успіхом Т. Левчука, схвалює «точно підібраний акторський ансамбль (...), чудову роботу з кольором і композицією оператора М. Кульчицького» [13]. Такої ж думки і Ю. Збанацький, який зауважив, що «ліпити образ вічного революціонера, славного і непримеренного Каменяра не всякий візьметься і не кожному він під силу. Не покоривсь Іван Франко повністю і молодому Левчукові, але все ж і до цього часу (до 1981 p. Aвт.) яскравішого Франка в кіно ми не бачили [6, с. 71$]$.

Значне місце в творчості Т. Левчука займають фільми про Другу світову війну. Як учасник бойових дій - лейтенант зв'язку, майор, начальник окремого батальйону зв'язку військової частини під командуванням Г. Муханова - він відчував відповідальність «за пам'ять про тих, хто загинув» [14]. Так, наприклад, у 1958 р. на Київській кіностудії ім. О. Довженка Т. Левчук розпочинає зйомки трьохсерійного фільму «Киянка» (сценарій І. Луковського), драматичної історії родини киян на фоні бурхливих подій 1917-1957 pp., у якому відтворено «активний опір та патріотичну боротьбу радянських людей в окупованому Києві супроти ворога» [6, с. 71]. У склад знімальної групи ввійшли: оператор М. Кульчицький, композитор Г. Жуковський, художники О. Степаненко, а також брали участь актори: Ю. Чирков, Н. Іванова, В. Гусєв, К. Скоробогатов, П. Куманченко, Ю. Максимов, А. Шестопалов, І. Переверзев, В. Грудинін, О. Жаков, Г. Ільїна, Н. Зорська, П. Паньов, Т. Коваленко, М. Криницина, О. Лебєдєв, В. Зиновєв, Д. Смірнова, І. Любич, С. Курилов, Ю. Прокопович, Ф. Іщенко, В. Смельянов, В. Судьїн, Ф. Радчук, П. Міхневич, Л. Татьянчук, О. Соколова, О. Толстих, Л. Данчишин, Л. Бордуков, Л. Вертинська, В. Квітка, В. Ларіонов, С. Дворецький, Л. Левчук, О. Борисов, П. Грубник, В. Ковальков, К.Сршов, Л. Снєжицький, В. Халатов та ін.

Прем'єра першої серії відбулася 3 листопада 1958 р., а 19 січня 1959 р. в прокат вийшла друга серія. Третю - «Нащадки» демонстрували в кінотеатрах з 12 листопада $1960 \mathrm{p}$.

Про фільм багато писалося в пресі: обговорювалися невиграшні епізоди сценарію - «причина всех бед лежит в плохом сценарии, основанном на шаблоне, на давно отработанных ситуациях» [12, с. 30] та гра акторів, огріхи операторської роботи тощо.

У 1962 p. Т. Левчук здійснює постановку першого українського широкоформатного кольорового художнього фільму «Закон Антарктиди», за 
сценарієм С. Олексеєва та Б. Чалого, написаного на реальних подіях, що відбулися в грудні 1958 р. У склад знімальної групи увійшли: оператори С. Шахбазян, Н. Слуцький та Л. Штифанов, композитор Г. Жуковський; брали участь актори: В. Сафонов, Р. Муратов, О. Мовчан, П. Морозенко, В. Волчик, В. Колокольцев, М. Крюков, Г. Тонунц, А. Матешко, Г. Ген, А. Моторний, В. Дальський, Л. Левчук, Л. Леонідов, Р. Дамбран, С. Дворецький, Л. Степанов, В. Скурстене, Х. Лієпіньш, В. Срмолаєв, В. Брежнєв, П. Варанді.

Т. Левчук та знімальна група відтворили кілька днів з життя радянських полярних пілотів, які в складних природних умовах, рятували групу бельгійських полярників, літак яких потерпів аварію посеред Антарктиди, в районі Перлових гір. Натурні зйомки відбувалися на Півночі, в реальних умовах. Виконавець головної ролі В. Сафонов (Віктор Бєлов) відмовився від дублерів і, для вірогідності зображення, виконував особисто складні трюки.

Прем'єра фільму відбулася 18 січня 1963 р. У Держкіно СРСР йому присуджено першу категорію, тобто стрічка стала видатним досягненням радянського кінематографу.

У 1964 р. Т. Левчук знімає широкоформатну драму «Космічний сплав», за сценарієм А. Первенцева. У знімальній групі працювали: оператор В. Войтенко, композитор Г. Жуковський, художник О. Бобровніков. На зйомки запросили акторів: О. Ханова, Н. Веселовську, М. Ріжова, М. Сидорківа та ін.

За жанром кінокартина тяжіла до науково-фантастичної, хоча насправді була драмою, розповідала про створення радянськими вченими,що створювали ракети та робітниками металургійного заводу нового надміцного сплаву, необхідного для створення космічних кораблів.

Всесвіт Т. Левчука не обмежувався лише творчістю - 31960 р. він викладач, а 31970 р. - професор Київського театрального інституту ім. І. К. Карпенка-Карого; за його сприянням у 1961 р. постановою Ради Міністрів УРСР відкрито у виші кінофакультет, навчальний корпус якого знаходився в Державному історико-архітектурному заповіднику «Києво-Печерська Лавра».

Великої уваги заслуговує діяльність Т. Левчука як голови Спілки кінематографістів УРСР, заснованої постановою Ради Міністрів СРСР від 6 лютого 1958 р. як регіонального відділення Спілки кінематографістів СРСР [2, с. 189]. Згідно зі Статутом, який затвердили на першому з'їзді Спілки, в листопаді 1963 р. [16], творча організація, окрім сприяння розвитку національних екранних мистецтв та розробці концепцій розвитку кіногалузі [17], популяризувала кращі фільми українського виробництва, проводила фестивалі, кінопрем'єри, творчі зустрічі; здійснювала захист авторських, професійних та громадських прав членів СК.

Відомий український кінорежисер М. Мащенко відзначав: «Куди б не кидала його доля - всюди Тимофію Васильовичу допомагала залишатись Людиною і Художником його любов до людей. Він сповідував іï в бою, виборюючи свободу людини, він сповідував її в кожному своєму фільмі. Багато років стверджував Левчук це почуття, очолюючи Спілку кінематографістів України [10]. Режисер М. Донской, характеризуючи організаторські здібності 
Т. Левчука, стверджував, що без його підтримки створення найкращих фільмів українського кінематографу так і лишилися б на стадії планування: «Тимофій Левчук звалив на свої плечі весь труд, усю складність виведення кіностудії у Києві з такого критичного стану, який не передвіщав їй нічого доброго. Він пішов найважчим шляхом: не повторюватися, не шкодувати сил, постійно працювати, не прикриваючись ні браком хороших сценаріїв, нічим іншим. Левчук ніколи не ставав на шлях підміни письменника-сценариста... Взагалі, він $з$ тих режисерів, які уміють працювати в колективному мистецтві кіно. Це дуже важлива режисерська риса» [9].

Наукова новизна статті полягає у висвітленні діяльності українського кінорежисера Т.В. Левчука в період хрущовської «відлиги», з використанням архівних матеріалів Київського національного університету театр, кіно і телебачення ім. І. К. Карпенка-Карого, фондів музею Національної кіностудії художніх фільмів ім. О. Довженка, критичних статей та рецензій, опублікованих у періодичній пресі, а також мемуарної літератури.

Висновки. Особистий внесок Т. В. Левчука в розвиток українського кіновиробництва та професійної мистецької освіти важко переоцінити: за його поданням у 1961 р. Ради Міністрів УРСР ухвалила рішення про відкриття в Київському інституті театрального мистецтва кінофакультету, який повинен здійснити підготовку кадрів за спеціальностями: кінорежисура, кіно операторство та кінознавство; наслідком його педагогічної діяльністі є виховання славетної когорти кінорежисерів; а творчої діяльності - художньо-ігрові фільми: «Полум’я гніву» (1955р.), «Іван Франко» (1956 р.), «Киянка» (1959р.), «Закон Антарктиди» (1962р.), «Космічний сплав» (1964р.), які потребують сьогодні незаангажованого осмислення.

\section{Список використаних джерел}

1. Бауман Е. О советском кинематографе / Е. Бауман // Советская культура. - 27. ноябр. - 1958. - С. 8.

2. Горячев Ю. И. Источник силы. О партийном руководстве развитием советской кинематографии / Ю. И. Горячев, В. В. Шинкаренко. - Москва : Искусство, 1984. - С. 189.

3. Зоркая Н. М. История советского кино / Н. М. Зоркая. - СанктПетербург : Алетейя, 2002. - С. 452.

4. Левчук Т. С любовью к зрителям / Т. Левчук. - Москва : Бюро пропаганды советского киноискусства, 1974. - 64 с.

5. Левчук Т. [Електронний ресурс] / Національна спілка кінематографістів України. - Режим доступу : http://www.ukrkino.com.ua/people/?id=553. - Дата звернення 10 листопада 2017.

6. Література та культура Полісся. Із літературної спадщини Ю. О. Збанацького (до 90-річчя від дня народження) / відп. ред. і упорядник Г. В. Самойленко. - Ніжин : Вид-во НДУ ім. М. Гоголя, 2004. - Вип. 26. - 188 с.

7. Кирдан В. Рецензия на фильм «Иван Франко» Т. Левчука // Московский комсомолець. - 24 янв. - 1957. - С. 6. 
8. Кузнецов В. Искусство или искусственность? / В. Кузнецов // Искусство кино. - 1958. - № 12. - С. 101-109.

9. Мащенко М. П. Роки і фільми кіностудії ім. О. Довженко [Електронний ресурс] / М. П. Мащенко // Світ екрану. - Режим доступу : http://svitekranu.org.ua/masch.htm. - Назва з екрану. - Дата звернення 22.10.2017.

10. Мащенко М. Тимофій Левчук. 3 любов’ю в серці / М. Мащенко // Правда України. - 20 січн. - 2012. - С. 6.

11. Михалевич А. Советский биографические фильмы / А. Михалевич // Искусство кино. - 1965. - № 3. - С. 13.

12. Погожева Л. Черты нового в современном советском киноискусстве // Вопросы киноискусства : ежегодный историко-теоретический сборник. Вып. 4. - Москва : АН СССР, 1960. - С. 5-48.

13. Тримбач С. У лабіринті історії [Електронний ресурс] / С. Тримбач // День. - Режим доступу : http://www.day.kiev.ua/222292. - Назва з екрану. - Дата звернення 20.10.2017.

14. Яновська Л. Інтерв'ю з Л. Левчук / Л. Яновська // Урядовий Кур'єр. 19 січн. - 2012. - С. 6.

15. Хигерович Е. Рецензия на художественный фильм Т. Левчука «Пламя гнева» / Е. Хигерович // Тихоокеанская звезда. - 27 июл. - 1956. - С. 6.

16. ЦДАГО України, ф. 1, оп. 31, спр. 3460, арк. 3

17. ЦДКФФА України імені Г. С. Пшеничного. - од. обл. 2756.

18. Чабаненко И. Пути украинского киноискусства / И. Чабаненко // Искусство кино. - 1958. - № 10. - С. 111-114.

\section{References}

1. Baumann, A. (1958). 'On Soviet cinema'. Sovetskaya kul'tura [Soviet culture], November 27, p.8.

2. Goryachev, Yu. (1984). A source of power. The party leadership on the development of Soviet cinematography. Moscow: Iskusstvo.

3. Zorkaya, N. (2002). The History of Soviet cinema. St. Petersburg: Aletheia.

4. Levchuk, T. (1974). With love to the audience. Moscow: Biuro propagandy sovetskogo iskusstva.

5. Levchuk, T. National Union of Cinematographers of Ukraine, [online] Available at: <http://www.ukrkino.com.ua/people/?id=553> [Accessed 10 November 2017].

6. Kirdan, V. (1957). 'Review of the film «Ivan Franko» by T. Levchuk'. Moskovskii Komsomolets [Moscow Komsomolets], January 24, p. 6.

7. Kuznetsov, V. (1958). Art or artifice? Iskusstvo kino [Art of cinema], no. 12, pp. 101-109.

8. Mashchenko, M. (2003). 'Years and films of the Dovzhenko Film Studios'. Svit ekranu [The World of Screen], [online] Available at: <http://svitekranu.org.ua/ masch.htm> [Accessed 22 October 2017].

9. Mashchenko, M. (2012). Tymofii Levchuk. With love in your heart. Pravda Ukrainy [The Truth of Ukraine], January 20, p. 6. 
10. Mikhalevich, A.(1965). Soviet biographical films. Iskusstvo kino [Art of cinema], no. 2, p. 13.

11. Pogozheva, L. (1960). Features of the new in modern Soviet cinema. Voprosy kinoiskusstva: ezhegodnyi istoriko-teoreticheskii sbornik [Problems of cinematography: the annual theoretical and historical collection], issue, 4, pp. 5-48. Moscow: Akademiya nauk SSSR.

12. Trymbach, S. (2012). 'In the labyrinth of history'. Den [Day], [online] Available at : <http://www.day.kiev.ua/222292>. [Accessed 20 October 2017].

13. Yanovska, L. (2012). Interview with L. Levchuk. Uriadovyi kurier [Government courier], January 19, p. 6.

14. Higerovich, E. (1956). 'Review of the film by T. Levchuk "The flame of wrath". Tikhookeanskaya zvezda [Pacific star], July 27, p. 6.

15. Tsentralnyi derzhavnyi arkhiv hromadskykh ob'iednan Ukrainy [The Central State Archive of Civil Groups], f. 1, op. 31, SPR. 3460, ark. 3

16. State Photo Archive of Ukraine named after G. S. Pshenichnyi, od. 2756.

17. Samoilenko, H. ed. (2004). Literature and culture of Polissya. Of the literary heritage of $\mathrm{Yu}$. Zbanatskyi (to the 90th anniversary of birthday) Nizhyn: Vydavnytstvo Nizhynskoho derzhavnoho universytetu imeni M. Hoholia.

18. Chabanenko, I. (1958). The ways of Ukrainian cinema art. Iskusstvo kino [Art of cinema], no. 10, pp. 111-114.

(C) Сокол Е. В., 2018

\title{
УДК 792.028:001.89
}

\author{
Хлистун Олена Сергї̈вна \\ кандидат мистецтвознавства, \\ Київський начіональний університет \\ культури і мистецтвь, \\ Київ, Украӥна \\ with_joy@ukr.net
}

\section{КАТЕГОРІАЛЬНИЙ АПАРАТ ДОСЛІДЖЕННЯ ФЕНОМЕНУ СЦЕНІЧНОГО ПЕРЕВТІЛЕННЯ АКТОРА}

Метою роботи $\epsilon$ упорядкування наукової термінології, пов'язаної з феноменом сценічного перевтілення актора. Методологія дослідження базується на принципах системності й єдності теоретичного та емпіричного при феноменологічному підході до процесу самореалізації особистості. Використовувався метод фільтрації при відборі категорій для дослідження процесу образного перевтілення актора. Наукову новизну становить виявлення та систематизація категорій i понять щодо дослідження майстерності перевтілення актора в художній образ. Висновки. Основними категоріями та концептуальними поняттями, які застосовуються в дослідженні проблеми 